\title{
DERMOCYSTIDIUM BRANCHIALE LĖGER, 1914 (HAPLOSPOREA) FOUND ON THE GILLS OF A COMMON TROUT (SALMO TRUTTA) FROM THE RIVER SVRATKA (CATCHMENT-AREA OF THE DANUBE)
}

\author{
Z. LUCKÝ and L. GROCH ${ }^{1}$
}

Department of Poultry, Fish, Bee and Wild Animal Diseases, and Department of Pathological Morphology and Parasitology ${ }^{1}$, University of Veterinary Science, 61242 Brno

Received November 16, 1987

$$
\text { A b s t r a c t }
$$

L u c k ý Z., L. G r o c h: Dermocystidium branchiale Lèger, 1914 (Haplosporea) Found on the Gills of a Common Trout (Salmo trutta) from the River Svratka (Catchment-Area of the Danube). Acta vet. Brno, 57, 1988: 53-60.

The finding of haplosporidia of Dermocystidium branchiale on the gills of a common trout (Salmo trutta) from the river Svratka near Doubravnik (catchment-area of the Danube) is reported: It is a second finding of this parasite in Czechos lovakia.

Spherical cysts produced by the haplosporidia on the gill filaments were 0.15 to $0.44 \mathrm{~mm}$ in diameter and contained spherical spores of 6 to $10 \mu \mathrm{m}$ in diameter. Histological examination revealed moderate regressive changes in the respiratory epithelium of the gills.

Dermocystidium branchiale, Haplosporea, Salmo trutta, gills, spores.

The incidence of parasites in common trout (Salmo trutta) in Bohemian and Moravian rivers has received rather considerable attention in the past few decades as evidenced by their list in the compendium by $\mathrm{E} \mathrm{g}$ e $\mathrm{n} \mathbf{s}$ and $L \circ \mathrm{m}$ (1970). According to these writers the species Dermocystidium branchiale has been found so far in Swiss and Irish rivers and its incidence in Czechoslovakia is regarded by them as .very probable. Their presumption was confirmed by us within an investigation into the health status of common trout ( $S$. trutta) in the river Svratka by the finding of cysts containing mature spores of haplosporidia of Dermocystidium branchiale on the gills of one common trout.

The incidence of $D_{\text {. }}$ branchiale in European rivers seems to be rather rare. According to $\mathrm{L}$ e e r (1914) as cited by $J i r o v$ e c (1939) this species was found on the gills of Trutta fario in the Dauphinean Alps and was described as a sp. $n$. $D$ u $n k$ e 1 y (1914) as cited by

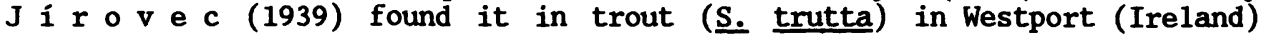
and identified it as the species Dermocystidium pusula that $P$ è $r$ e $z$ (1907) had found in the skin of the newt (Triturus marnoratus) in France and called Dermocystis pusula.

The information on Dermocystidium branchiale (description and the place of its finding) in parasitological and ichtyopathological compendia (D y k 
1954; B y c h o v s k $\mathrm{i}$ et al. 1962; E r g n s and L o m 1970; S c $h \ddot{a}$ p e r c 1 a u s et al. 1979; B a u e r 1984) are based on the data supplied by $L$ è $g$ e $r$ (1914).

The first finding of $\underline{D}$. branchiale in $\mathrm{fish}$ in Czechoslovakia was reported by $\mathrm{P}$ a 1 á $\mathbf{s} \quad k$ o $v$ á (1985) who found it on the gills of common trout in the brook Borovnice in South Bohemia in 1980. Besides the description of the specimens, her report is concerned with the taxonomy of the genus Dermocystidium, its species known hitherto, seasonal occurrence of $D$. branchiale and infection experiments with this species.

The epizootiological role and pathogenesis of Dermocystidium sp - were considered by $R \circ b$ e $\mathrm{r} s$ and $\mathrm{S}$ ch 1 o t fe ldt (1985) with reference to the finding of $P$ a $u$ e $y$ (1967) that dermocystidiosis caused $25 \%$ mortality among 5000 adult Pacific salmon of the species Onchorhynchus tschawytscha. A 11 e $n$ et al. (1968) described a similar disease not only in adult salmon of the aforementioned species but also in fingerlings and concluded that an outbreak of the disease is favoured by temperature lower than $15^{\circ} \mathrm{C}$.

In Europe, $W$ o o t $t$ e $n$ and Mc V i c a r (1970) described a massive infection in Atlantic salmon in Scotland where particularly young salmon were affected. They found numerous small cysts, $1 \mathrm{~mm}$ in diameter, on the gills of adult salmon and described the causative agent as a Dermocystidium sp., without further identification. The wall of the cyst described in their study consisted of fine fibrous tissue and the adjacent gill epithelium was hyperplastic. In some Atlantic salmon they found parasites also in other organs (adipose network of the body cavity, liver, heart, spleen, pancreas and pyloric appendices) and only rearely in the gills and regarded them as members of another species. According to $P r$ o $t$ (1980) the hosts of $D_{\text {. }}$ branchiale are the sea trout (Salmo trutta) and the common trout and the pathological role of the parasite is small.

\author{
Materia 1 s a nd Method s
}

Four common trout, 195 to $226 \mathrm{~mm}$ in length and 85 to $141 \mathrm{~g}$ in body mass, from the river Svratka (near Doubravnik) were subjected to parasitological examination on the 3rd of June 1987. Six common trout, 198 to $251 \mathrm{~mm}$ in length and 96 to $138 \mathrm{~g}$ in body mass, from the same river were obtained for examination on the 11th of August 1987. Another 6 common trout, 175 to $210 \mathrm{~mm}$ in length and 68 to $135 \mathrm{~g}$ in body mass, from a stream called Nedvědička (near Věžná) were examined on the 3rd of August 1987. The Nedvědička is tributary to the Svratka and the two localities from which the trout were obtained are about $10 \mathrm{~km}$ apart. Cysts on the gills (40 specimens) were diagnosed only in one common trout from the first locality on the 3rd of June 1987.

The fresh material was fixed with $4 \%$ formol. For species identification, native slide preparations and preparations stained with Giemsa stain and with haematoxylin and eosin were prepared. Histological processing was carried out with routine methods using paraffin blocks stained with haematoxylin and eosin and with van Gieson stain.

$R$ e $s$ u $1 \mathrm{t}$

Description of the Parasite and of the Pathological Changes

Species: Dermocystidium branchiale

Host: Common trout (Salmo trutta) 


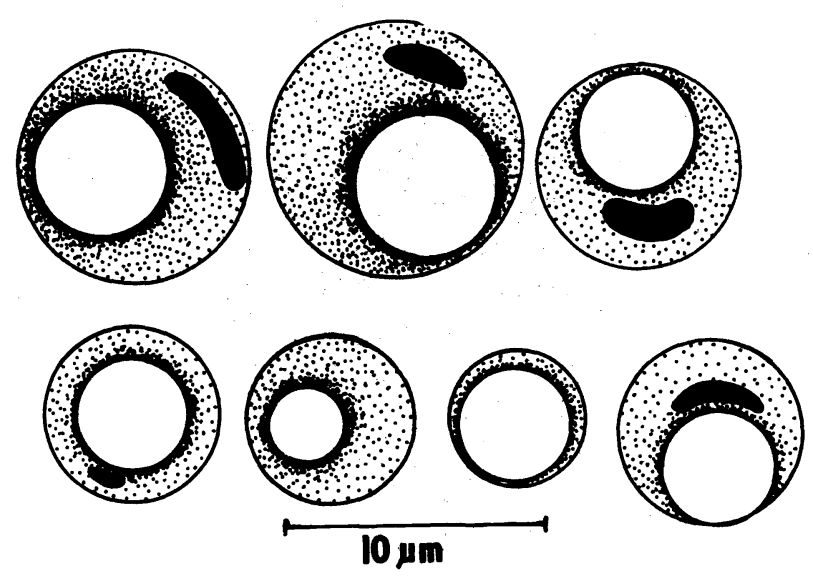

Fig. 1. Spores of Dermocystidium branchiale showing a large refractive vacuole and the elongated nucleus.

Locality: The river Svratka (near Doubravník) catchment-area of the Danube

Location: Gills

Intensity: 40 cysts

Percentage of trout infected: $10 \%$ ( 1 out of 10 trout examined)

Mature spores were almost spherical in shape and generally $8 \mu \mathrm{m}$ (6 to $10 \mu \mathrm{m})$ in diameter. Examination of the native and $4 \%$ formol-stained preparations showed that the spores contained large, spherical, highly refractive homogenous bodies that were generally located excentrically and some of them could be seen even at the rim of the spore. Their size (4 to $6 \mu \mathrm{m}$ in diameter) was proportional to that of the spore. Some spores showed the presence of a spherical or elongated, frequently slightly bent formation of varying size. In Giemsa-stained preparations, heavily-staining irregular formations suggestive of the nucleus could occasionally be seen in addition to the refractive body.

In histological sections stained with haematoxylin according to Mayer the staining of the nuclei was very intense. The elongated nuclei were 0.002 to 0.003 times $0.002 \mu \mathrm{m}$ in size.

The spores were located in small cysts. The cysts exhibiting a marked wall and spherical in shape were found 

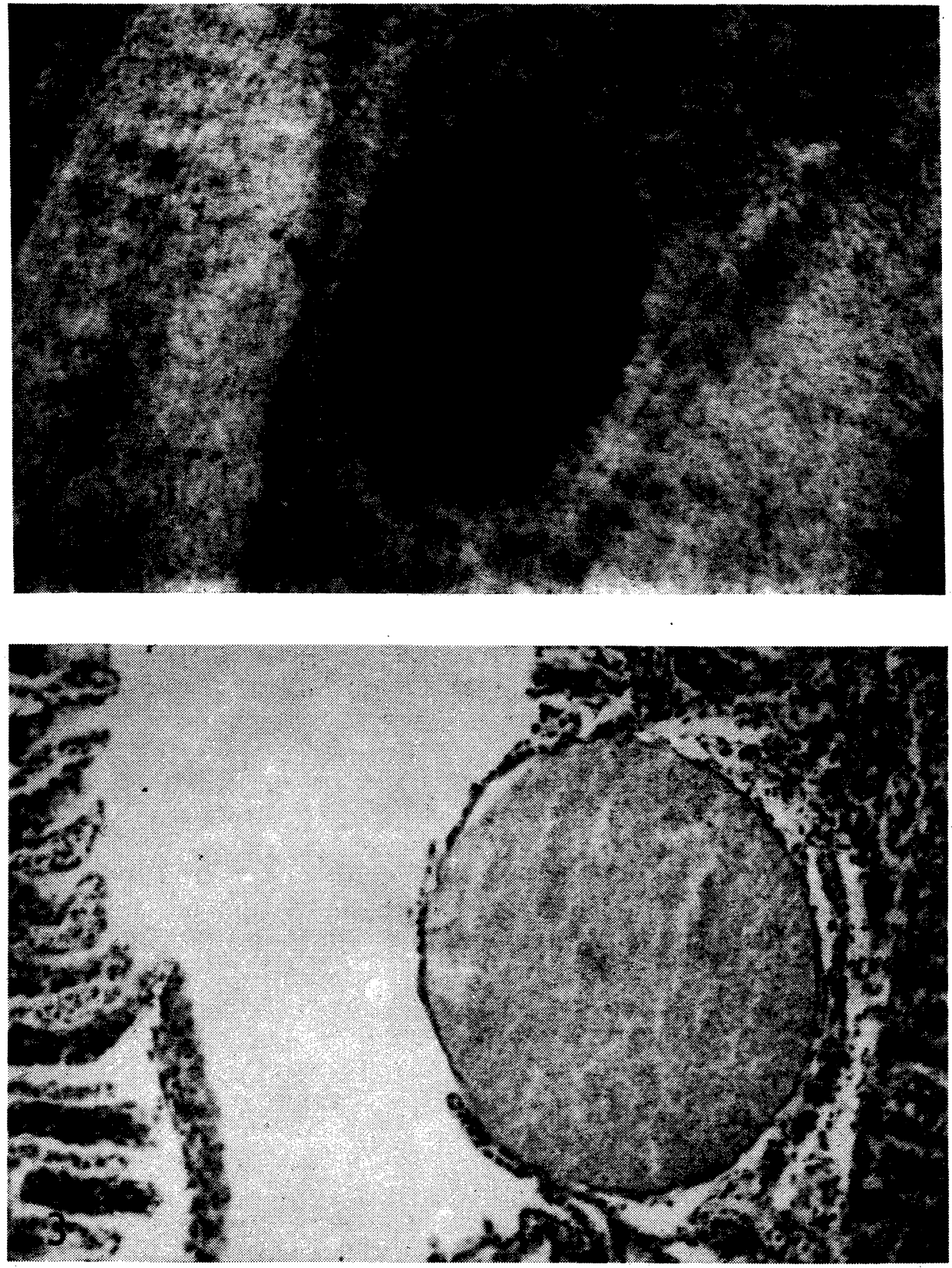

Fig. 2. A cyst of Dermocystidium branchiale between the gill filaments (compression preparation; magnification: obj. x10, oc. $x 7$ ).

Fig. 3. A cyst of Dermocystidium branchiale located between respiratory plate-like projections of the gill filament and showing a distinct capsule (histological section, $\mathrm{HE}$; magnification: obj. $\mathrm{x} 10$, oc. $\mathrm{x} 7$ ). 

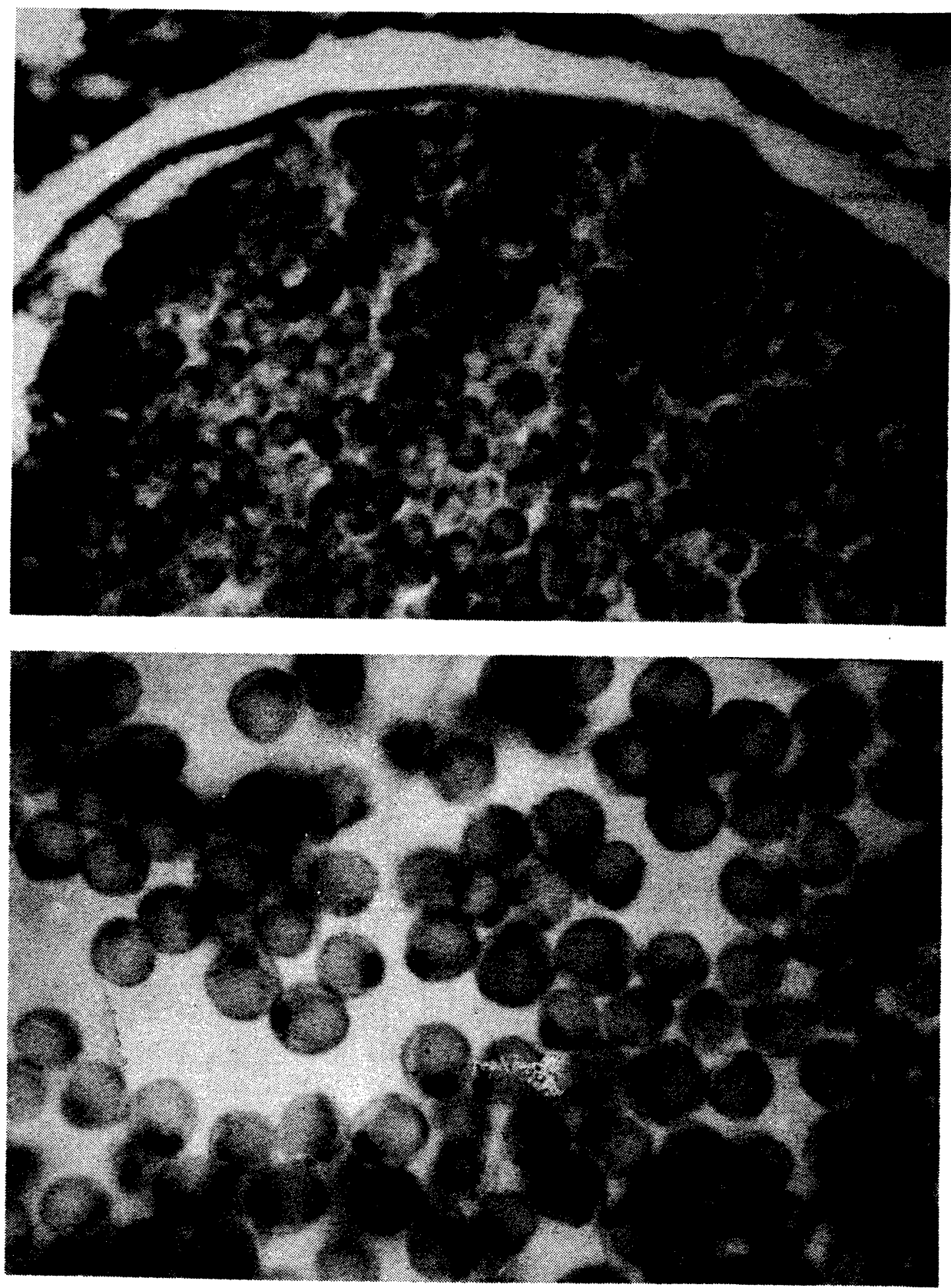

Fig. 4. Part of a cyst of Dermocystidium branchiale with the distinct membrane of the parasite (histological section, van Gieson; magnification: obj. $\times 45$, oc. $\times 7$ ).

Fig. 5. Spores of Dermocystidium branchiale showing dark nuclei at the periphery (histological section, HE; magnification: obj. x60, oc. x7). 


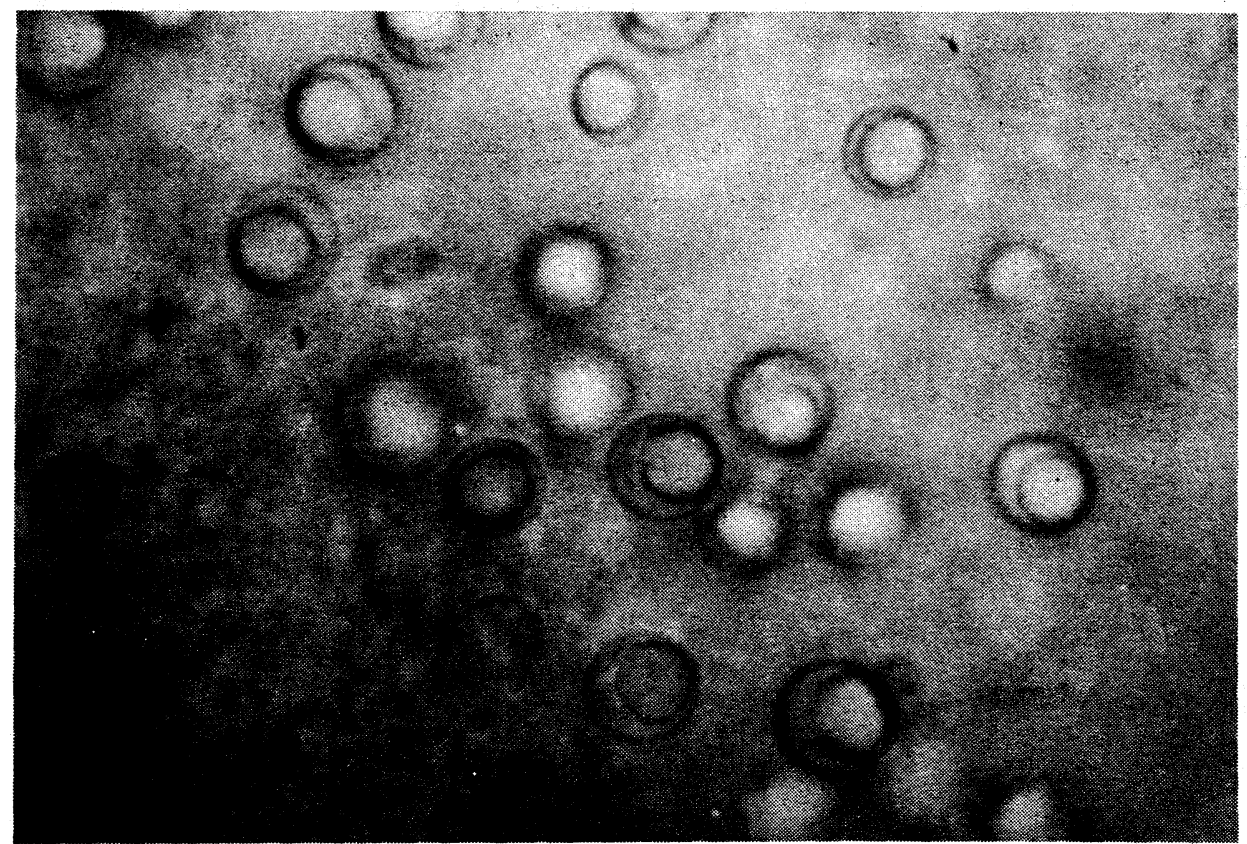

Fig. 6. Spores of Dermocystidium branchiale showing large excentrically located vacuoles (native preparation; magnification: obj. $x 60$, oc. $x 7$ ).

on the gills both at the base of gill filaments and in the medium and peripheral parts. They were often located between respiratory plate-like projections in the stratified gill epithelium or in the respiratory epithelium. The cysts showed considerable variation in size (15 cysts measured in our study ranged from 0.150 to $0.440 \mathrm{~mm}$ in diameter).

Histological examination of the gill samples revealed spherical cystic formations of varying size,generally located between gill filaments. They were enclosed with a delicate capsule of filamentous collagen and showed a slightly basophilic granulated content that proved to be a dense accumulation of spherical spores when examined under higher magnification. Inside the spore a large light vacuole was located slightly excentrically. Its content did not stain with alcian blue and therefore contained no acid mucopolysaccharides. Positive reaction for mucopolysaccharides was shown only by the cell membrane. Located at the periphery of the spore was the basophilic ovoid or slightly curved nucleus. 
The respiratory epithelium adjacent to the cysts showed regressive changes of various degree: it was atrophic at the sites of direct contact with the cysts and showed dystrophic injury manifested by vacuolization of the cytoplasm, impaired outline of the cell and occasionally also by necrobiotic changes of the nuclei in more distant areas. A frequent accompanying finding was passive hyperaemia of the gill tissue. No reactive inflammatory processes at the gill epithelium adjacent to the cysts were observed. This finding suggests that the cysts in the gill tissue increase slowly and do not produce a morphologically distinct defensive response of the host.

Dermocystidium branchiale Lèger, 1914 (Haplosporea) cizopasník žaber Salmo trutta z řeky Svratky (povodí Dunaje)

Práce hodnotí výskyt haplosporidie Dermocystidium branchiale a popisuje druhý nález tohoto druhu $z$ území ČSSR. Cizopasník byl zjištěn jen u 1 pstruha obecného $v$ řece Svratce (povodí Dunaje) u města Doubravnịku v měsíci červnu 1987.

Haplosporidie vytvářely na žaberních lístcích kulovité cysty velikosti $0,15-0.44 \mathrm{~mm}$ a obsahovaly kulovité spory velikosti 6 - $10 \mu \mathrm{m}$. Histologickým vyšetřením byly zjištěny v respiračním epitelu žaber mírné regresní změny.

Dermocystidium branchiale Lèger 1914 (Haplosporea) жаберный паразит Salmo trutta реки Свратки/бассейна дуная

В работе дается оценка наличия гаплоспоридии Dermocystidium branchiale и описание второго по счету выябления данного вида на территории ЧССР. Паразит был установлен лишъ Y одной форепи в реке Свратке (басейн дуная) около города Доубравник в июне 1987 г.

Гаплоцпоридии образовали на листиках жабр шарообразные кисты величиной 0,15-0,44, мм содержащие шарообразные споры размером 6 - 10 мкм. Гистологическими исследованиями были в эпителии дыхателъных путей установлены незначителъные регрессивные изменения. 
ALLEN, R. - MELKIN, T. - PAULEY, G. - FUJIHARA, M.: Mortality among chinook salmon associated with the fungus Dermocystidium. J. Fish. Res. Bd Can., 25, 1968: 2467 - 2475.

BAUER, 0. et al.: Opredèlitel parazitov presnovodnych ryb fauny SSSR. Parazitičeskije prostějšije. Izdatělstvo "Nauka", Leningrad, 1984: 428 p.

BYCHOVSKIJ, E. et al.: Opredělitel parazitov presnovodnych ryb SSSR. Izdatělstvo AN SSSR, Moskva-Leningrad, 1962: 776 p.

DUNKERLY, J.: Dermocystidium pusula Perez parasitic in Trutta fario. Zoo1. Anz., 44, 1914: 179 (cit. Jirovec, 1939).

DYK, V.: Nemoci našich ryb. Nakladatelství CSAV, Praha, 1954: 391 p.

ERGENS, R. - LOM, J.: Pưvodci parasitárnich nemoci ryb. Nakladatelstvi CSAV, Praha 1970: 383 p.

JfROVEC, 0.: Dermocystidium vejdovskyi n.sp. ein neuer Parasit des Hechtes, nebst einer Bemerkung über Dermocystidium daphniae (Rüberg). Archiv für Protistenkunde, 92, 1939: 137 - 146.

LÈGER, L.: Sur un nouveau Protiste du genre Dermocystidium parasite de la Truite. C.r. Acad. Sci. Paris, 158, 1914: 807 (cit. Jirovec, 1939).

PALÁSKOVÁ, M.: Record of Dermocystidium branchiale Leger, 1914 in Salmo trutta $\mathrm{m}$. fario in South Bohemia. Folia Parasitologica (Praha), 32, 1985: 293 - 294.

PAULEY, G.: Prespawning adult salmon mortality associated with a fungus of the genus Dermocystidium. J. Fish. Res. Bd Can., 24, 1967: 843 - 848 .

PEREZ, Ch.: Dermocystis pusula, organisme nouveau parasite de la peau des Tritons. C.r. Soc. Biol. Paris., 63, 1907: 445 (cit. Jírovec, 1939).

PROST, M.: Choroby ryb. Pañstwowe Wydawnictvo Rolnicze i Lešne, Warszawa, 1980: $437 \mathrm{p}$.

ROBERTS, R. - SCHLOTFELDT, H.: Grundlagen der Fischpathologie. Paul Parey, Berlin und Hamburg. 1985: 425 p.

SCHÄPERCLAUS, W. et a1.: Fischkrankheiten. Akademie-Verlag, Ber1in, 1979: $1089 \mathrm{p}$.

WOOTTEN, R. - McVICAR, H.: Dermocystidium sp. A new protozoon disease of Farmed Atlantic Salmon. In: Proceedings in Life Sciences: Fish Diseases. Third COPRAQ-Session. Ed. by W. Ahne. Springer Verlag, Berlin, Heidelberg, New York, 1980: 165 - 173. 